\title{
Effect of Aerobic Exercise on Factors Relative to the Brain Nerve Growth in Girls
}

\author{
Mi-Young Pyun, Han-Sam Cho, Jae-Young Jeon, Jong-Won Kim, Kyung-Hee Lee, Chun-Kyu Lim, \\ $\mathrm{Tae}^{-U n} \mathrm{Kim}^{1 *}$, Hyun-Jun $\mathrm{Kim}^{2}$, Yi-Sub $\mathrm{Kwak}^{3}$ and Ki-Jun $\mathrm{Ko}^{4}$
}

${ }^{1}$ Department of of Physical Education, Pusan National University, Busan 609-735, Korea

${ }^{2}$ Department of Physical Education, Kyungnam University, Masan, Kyungnam 631-701, Korea

${ }^{3}$ Department of Physical Education, Dong-Eui University, Busan 614-714, Korea

${ }^{4}$ Department of Sport for All, Daegu Mirae College, Gyeongsan, Gyeongbuk 712-716, Korea

Received May 8, 2010 / Accepted June 23, 2010

\begin{abstract}
Exercise can favorably influence brain plasticity by facilitating neurogeneration, neuroadaptivity, and neuroprotection. Aerobic exercise has been reported to change brain nerve growth factors (growth hormone, insulin like factor-1, estrogen and serotonin). The purpose of this study was to demonstrate the effects of aerobic exercise for 12 weeks on brain nerve growth factors in girls. Fourteen female participants in elementary school grades 1 through 3 were randomly allocated to the exercise group $(E G, n=6)$ and control group $(C G, n=8)$. The EG participated in 60 minutes of modified ballet exercise as aerobic training three days a week for 12 weeks. Based on comparison between groups by two-way ANOVA with repeated measures, aerobic exercise program participants experienced decreased weight $(p<0.01)$, BMI $(p<0.01)$, fat mass $(p<0.001)$, fat percent $(p<0.001)$ and increased LBM (lean body mass) percent $(p<0.001)$. In addition, we detected that aerobic exercise decreased the level of serotonin $(\mathrm{p}<0.05)$ and increased the level of GH $(\mathrm{p}<0.05)$ and IGF-1 $(\mathrm{p}<0.05)$. These findings suggest that aerobic exercise programs can be an efficient intervention to change body composition, alleviate central fatigue, improve brain function, and induce brain cell proliferation in girls.
\end{abstract}

Key words : Aerobic exercise, brain nerve growth factor, IGF-1, estrogen, serotonin

\section{서 론}

우리나라는 취학 전 아동들부터 청소년에 이르기까지 과다 한 학업시간으로 인한 신체활동의 부족, 인스턴트식품의 과다 한 섭취 등으로 소아형 당뇨병, 퇴행성 관절염, 그리고 아동 비만이 증가하고 있는 추세이다[29]. 이러한 연구 결과에서 보 듯이 운동 부족은 운동기능의 발달 저해뿐만 아니라 신체적인 각종 질병과, 지적·정서적 장애를 일으키는 원인이 된다.

아동기는 일생 중에서 지능발달의 결정적 시기이며, 이 시 기의 지능과 신체발달 사이에는 밀접한 관련이 있는 것으로 보고되고 있다. 실제로 이 시기의 운동발달의 지연은 학습장 애의 원인이 되기도 하는데, 이는 운동발달이 단순히 신체적 인 동작에 국한된 것이 아니라 시각, 지각발달 및 신경조직의 발달과도 관계가 있기 때문이다[49].

뇌신경세포는 발달과정과 생후 초기에만 생성되며, 성인의 뇌에서는 더 이상 새로운 신경세포가 생성되지 않는다고 믿어 져 왔으나, 1990년대 이후 밝혀진 연구 결과에 의하면 성체동 물의 뇌에서도 새로운 신경세포가 생성되며, 실제로 뇌의 해 마, 대뇌피질, 후각망울, 뇌실 하층 영역에서 지속적인 신경세 포의 생성이 관찰되었다[16,20,21]. 이로써 신경세포의 증식,

\footnotetext{
*Corresponding author

Tel : +82-51-510-2727, 2647, Fax : +82-51-515-1991

E-mail : tukim@pusan.ac.kr
}

이동, 생존 및 분화를 조절하는 요인들을 찾기 위한 후속 연구 들이 활발히 진행되고 있다.

이와 같은 연구 중 운동이 뇌 기능에 미치는 효과에 대한 많은 연구가 진행되어왔다. 적당한 유산소운동은 인간의 인식 력과 기억력을 증가시키며[26], 운동이 생리적인 안정을 가져 오며[9], 뇌파에 긍정적인 효과를 미친다고 보고하였다[33,34]. 특히, 쥐를 대상으로 한 연구에서 유산소운동 후 해마에서 직 접적인 뇌세포 생성을 대표하는 인자인 $\mathrm{BDNF}$ 발현이 증가되 었다고 보고하였고[40,52], 트레드밀 달리기가 쥐의 해마 치상 회의 세포를 증식시킨다고 하였다[53].

선행연구들에서 운동의 효과로 보고된 기억력 증가, 생리적 인 안정, $\mathrm{BDNF}$ 발현 증가, 쥐의 해마 치상회의 세포 증식과 같은 뇌기능 활성과 뇌세포 생성을 유도하는 자극인자로는 $\mathrm{GH}$, IGF-1, estrogen, serotonin 등이 보고 되었다[6,10,11, 28,46].

성장인자인 GH는 IGF-1의 생성을 자극하는 역할을 하며, 운동에 의해 증가된 $\mathrm{GH}$ 와 IGF-1의 수준이 뇌의 $\mathrm{BDNF}$ 증가를 자극하는 것으로 보고되었다[10]. 특히, $\mathrm{GH}$ 는 뇌에서 자가 분 비되어 뇌기능 활성과 뇌세포 생성에 영향을 미치는 것으로 보고된 바 있다[23,38,47].

IGF-1은 간과 뇌, 다른 조직에서도 생성되며, 신경전달물질 과 인식작용에 관여한다[10,12,28]. 또한 유전자의 신경발생 $\mathrm{BDNF}$ 유전자 조절을 중재하고[11], 뇌에서의 신경단위 성장과 
분화에 관여하는데[2], 운동 후에는 뇌와 말초신경의 IGF-1 수 준이 증가되고, 뇌 혈관벽 주변을 가로지르는 신경 전달 물질 이 증가된다[44].

estrogen은 골 형성에 중요한 역할을 하는 골 흡수 지표로 알려져 있으며, estrogen이 부족하면 골 조직망이 손상을 입는 것으로 보고되었다[13]. 이와 같은 estrogen은 운동에 의해 증 가하는 것으로 보고되고 있는데[35], 최근에는 estrogen이 뇌 기능 활성 및 뇌세포 생성에도 관여하며, 뇌의 노화와도 관련 이 있으며 $[18,19]$, 뇌의 다양한 영역 및 말초동맥에서 발현되 어 뇌 신경 자극인자로 알려진 BDNF (brain-derived neurotrophic factor)에도 영향을 미치는 것으로 밝혀졌다[7,50].

serotonin은 통증, 피로, 식욕 및 수면과 관련이 있으며, 해 마의 $\mathrm{BDNF}$ 발현 및 수준을 증가시키는 물질로 알려져 있다 $[15,46]$. 신경전달물질인 serotonin은 운동에 의해 증가되는 것 으로 보고되어 있는데[41], 운동 중에 증가된 serotonin은 무력 감을 증가시키고 동기유발을 상실하게 함으로써 피로를 유발 하는 부정적인 면이 있는 반면에 serotonin과 운동 요법을 병 행한 우울증 치료가 약물요법 보다 $\mathrm{BDNF}$ 조절 능력을 강화 시켜 효과적이라는 긍정적인 면이 있어 운동에 의해 변화되는 serotonin의 중추신경 및 뇌세포 생성관 관련된 연구가 필요하 다[18,39].

다양한 선행연구를 통해 운동이 뇌기능 활성에 영향을 미치 는 것으로 보고되어 있지만 쥐를 대상으로 한 연구가 대부분 이다. 이러한 연구들은 운동형태가 제한적이며, 강제적인 자 극에 의한 운동이므로 운동효과에 대한 결과 해석을 인간에게 적용하기는 어렵다. 그러므로 사람을 대상으로 한 연구가 필 요하다. 또한, GH, IGF-1은 뇌기능 발달 및 뇌세포 성장뿐만 아니라 신체 성장과도 밀접한 관련이 있으므로 성장기 아동 을 대상으로한 연구가 필요하다.

이에 본 연구는 여자 아동을 대상으로 12 주간 유산소운동 프로그램을 실시하여 뇌기능 발달 및 뇌세포 생성 유도인자 (GH, IGF-1, estrogen, serotonin)의 변화를 분석하였다.

\section{재료 및 방법}

\section{연구대상}

본 연구의 대상은 초등학교 저학년 여자 아동을 대상으로 실험에 참여하기를 희망하고 보호자 동의서를 제출한 아동들 로 하였으며, 총 20 명의 대상자를 운동군에 10 명, 일상생활을 그대로 유지하는 대조군에 10 명을 무선 배치하였다. 그러나 실험기간 중 운동군에서 프로그램 참여에 흥미를 잃어 4 명이 중도 탈락하였으며, 대조군에서는 채혈 거부로 인해 2 명이 중 도 탈락하여 최종적으로 운동군 6 명, 대조군 8 명 총 14 명을 분석대상으로 하였다. 또한 최근 6개월 사이에 규칙적인 신체활 동 및 무용에 참여하였거나 특정 질환으로 치료를 받고 있는 학생은 제외하였으며, 대상자의 신체적 특성은 Table 1 과 같다.
Table 1. Physical characteristics of subjects

\begin{tabular}{lrrr}
\hline & \multicolumn{1}{c}{ EG $(\mathrm{n}=6)$} & \multicolumn{1}{c}{ CG $(\mathrm{n}=8)$} & \multicolumn{1}{c}{$t$} \\
\hline Age (age) & $6.50 \pm 0.55$ & $6.63 \pm 0.74$ & 0.735 \\
Height $(\mathrm{cm})$ & $127.95 \pm 6.69$ & $127.08 \pm 5.88$ & 0.799 \\
Weight $(\mathrm{kg})$ & $26.82 \pm 4.30$ & $26.51 \pm 1.88$ & 0.860 \\
BMI $\left(\mathrm{kg} / \mathrm{m}^{2}\right)$ & $16.30 \pm 1.75$ & $16.44 \pm 1.08$ & 0.859 \\
\hline
\end{tabular}

Values are means \pm SD.

EG: exercise group, CG: control group

BMI: body mass index

\section{측정항목 및 방법}

신체조성 측정은 신장, 체중, 체지방량, 체지방률, 제지방량 5 개 항목을 In body J10 (Biospace. Co. Korea)을 이용하여 측 정하였다. 정확한 측정을 위하여 검사 전 12 시간 동안 심한 운동을 삼가 하도록 주지하였으며, 4 시간 전부터 식 - 음료를 금하도록 하였다. 시계와 그 외 신체 부착물은 착용하지 않은 가벼운 옷차림으로 다리와 팔을 모으고 편안한 자세로 기기에 올라서게 하여 측정하였다. 제지방률은 제지방량을 체중으로 나눈 후 100 을 곱하여 구하였으며, BMI (body mass index)는 체중 $(\mathrm{kg})$ 을 신장의 제곱 값 $\left(\mathrm{m}^{2}\right)$ 으로 나누어 구하였다.

혈액분석 항목은 GH (growth hormone), IGF-1 (insulin like facter-1), estrogen, serotonin이다. 분석을 위해 전날 20:00 부터 12시간 이상 물과 음식을 제한한 공복상태를 유지하도록 통제하여 다음날 오전 09-10시에 채혈하였다. 간호사가 초등 학교를 방문하여 아동이 앉은 자세에서 약 $10 \mathrm{ml}$ 를 전완주정 맥(cubital vein)에서 채취하였으며, 이때 항고응제(ethyl diamine tetra acetate: EDTA)로 처리한 진공 채혈관 튜브를 사용 하였으며, 혈액분석은 다음과 같은 방법으로 분석되었다.

GH는 DPC-Immulite $2000 \mathrm{USA})$ 을 사용하였으며, 측정방 법은 비 경쟁반응을 이용하였으며, 검사시약은 $\mathrm{GH}$ control 시 약(제일)을 이용하였다. 측정원리는 고상법(solid phase)으로 항체가 피복된 구슬(beads)에 성장호르몬을 반응시킨 다음 표 지항체(125I-Anti GH)를 반응시켜 검체의 성장호르몬을 알리 는 sandwich원리이다. estrogen, IGF-1, serotonin 측정은 1,470 wizard $\gamma$-counter(Japan)를 사용하였으며, 측정방법은 비 경쟁반응(immunoradionmetric assay: IRMA)을 이용하였 다. 검사는 실온 $200 \mathrm{rpm}$ 에서 3시간 반응시켜 증류수로 트레 이 속의 구슬을 충분히 세척한 후 트레이의 구슬을 시험관에 옮겨 방사선량을 $\gamma$-Counter로 계측하였고, 이 때 표준액의 계측 값으로 표준곡선을 만들고 검체의 계측 값으로 표준곡선 에서 검체의 성장호르몬 농도를 측정하였다.

IGF-1은Toshiba YBA-200 FRNEO Japan)를 사용하였으며, 측정방법은 방사선 면역측정법(Radio-immunoassay: RIA)이 며, 검사시약은 IGF-I-D-RIA-CT로 하였다. 측정원리는 RIA의 기본 원리인 항체에 대해 항원과 표지항원이 경쟁적으로 반응 하는 경쟁반응을 이용하였다. 검사방법은 sample과 control을 21 배 희석하여 튜브에 $1 \mathrm{ml}$ 씩 분주하고, 해당 sample과 con- 
trol을 $5 \mathrm{ml}$ 씩 분주하여 섞어 실온에서 24시간(overnight) 반 응시켜 free form과 bound form을 $\gamma$-Counter로 분간 계측하 여 표준 graph에서 농도를 구하였다.

estrogen 분석은 ADVI0A Centaur (U.S.A)를 사용하였으 며, CLIA 검사법으로ADVIA Centaur estrogen kit (Bayer, USA)를 사용하여 분석하였다.

serotonin은 혈장 내 serotonin을 HPLC (High performance liquid chromatography)방법으로 검사시약인 Sodium acetate (Sigma, America), Citric acid (Sigma, America), Octyl sulfate (Sigma, America), Methanol TED Perch-ronic acid (Hayashi, Japen)를 사용하였으며, High-Performance Liqid Chromatography (Neuroblastoma Analyzer, Bio-Rad, USA)를 통해 분석하였다.

\section{운동프로그램}

운동 경험이 없는 아동의 신체적 능력을 고려하여 발레동작 을 수정한 유산소운동 프로그램을 12주간, 주3회(월, 수, 금), 1 회 총 60 분간 실시하였다. 1 주일간의 적응과정을 통해 음악 에 맞춰 바른 자세 및 동작을 이해하고 익히게 하였으며 무선 심박수 측정기인 X-trainer (Polar. Co.)를 이용하여 목표심박 수 범위에서 운동이 될 수 있도록 하였다. 준비운동과 정리운 동은 스트레칭을 각각 10 분 동안 실시하였다. 주운동은 발레 동작(플랙스, 쁘띠 주테, 앙 화쓰, 앙 우베흐, 앙 크 드 꼬베, 파 드 샤, 젯뗴, 호핑 스텝, 그랑 알레그로, 앙 디올, 앙 드당, 파드부레, 글리샤드 데리에르 와 드방, 아쌈브레, 바트망 탕듀, 글리샤드)을 운동 경험이 없는 아동의 수준에 맞게 수정하여 음악에 맞춰 각 동작을 연속적으로 실시하도록 구조화시켰으 며, 무선심박수측정기의 이용과 음악의 빠르기를 조절하였으 며, 점증적 과부하의 원리를 적용하여1-2주는 저강도(45-54\% HRmax), 3-12주는 중강도(55-65\% HRmax)로 40분 동안 실시 하였다[1]. 1-2주는 동작에 대한 적응과 운동프로그램에 대한 흥미를 고려하여 저강도의 운동강도로 설정하였고, 3-12주간 은 점진적으로 운동의 효과를 높이기 위해 중강도의 운동강도
로 설정하여 실시하였다.

\section{자료처리}

수집된 자료는 SPSS Ver. 15.0을 이용하여 각 측정 항목에 대한 평균값(M)과 표준편차(SD)를 산출하였다. 사전 실험군 과 대조군의 신체적 특성과 각 측정변인에 대한 동질성은 Independent $t$-test 검정으로 확인하였다. 각 집단내 프로그램 실시 전·후 차이 비교 분석은 Paired-Samples t-test 를 이용하 였으며, 프로그램 실시에 따른 집단과 시기 간의 상호작용 및 집단간 차이에 대한 주 효과 검정은 2-way ANOVA repeated measure를 이용하였다. 통계적 유의수준은 $a=0.05$ 로 하였다.

\section{결 과}

실험군과 대조군의 프로그램 전 대상자의 일반적 특성 및 신체구성과 뇌세포 생성관련 인자에 대한 동질성 검정을 Independent $t$-test를 이용하여 실시한 결과 모든 변인에서 유 의한 차이가 나타나지 않아 두 그룹이 동일함을 알 수 있었다.

12 주 운동 후 대상자의 특성 및 신체구성의 변화는 Table 2 와 같다. 집단과 시기 간의 상호작용효과는 체중 $(\mathrm{p}<0.01)$, BMI $(\mathrm{p}<0.01)$, 체지방량 $(\mathrm{p}<0.001)$, 체지방률 $(\mathrm{p}<0.001)$, 제지방 률 $(\mathrm{p}<0.001)$ 에서 유의하게 나타났다. 운동군 내의 운동 전·후 평균값을 비교한 결과 신장 $(\mathrm{p}<0.001)$, 제지방량 $(\mathrm{p}<0.01)$, 제지 방률 $(\mathrm{p}<0.001)$ 에서 유의한 차이를 보이며 증가하였으며, BMI $(\mathrm{p}<0.001)$, 체지방량 $(\mathrm{p}<0.01)$, 체지방률 $(\mathrm{p}<0.01)$ 은 유의한 차이 를 보이며 감소한 것으로 나타났다. 대조군 내의 12 주 전·후 평균값을 비교한 결과 체중 $(\mathrm{p}<0.01), \mathrm{BMI}(\mathrm{p}<0.01)$, 체지방량 $(\mathrm{p}<0.001)$, 체지방률 $(\mathrm{p}<0.001)$ 에서 유의한 차이를 보이며 증가 한 것으로 나타났으며, 제지방률 $(\mathrm{p}<0.001)$ 은 유의한 차이를 보 이며 감소한 것으로 나타났다.

뇌세포 생성 관련 인자의 변화는 Table 3과 같다. 집단과 시기 간의 상호작용효과는 GH ( $\mathrm{p}<0.05)$, IGF-1 ( $<<0.05)$, serotonin $(\mathrm{p}<0.05)$ 에서 유의하게 나타났다. 운동군 내의 운동 전·

Table 2. Changes of body shape, body composition after 12-weeks aerobic exercise

\begin{tabular}{|c|c|c|c|c|c|c|c|}
\hline \multirow{2}{*}{ Variable } & \multicolumn{2}{|c|}{ EG $(n=6)$} & \multirow{2}{*}{$t$} & \multicolumn{2}{|c|}{ CG $(n=8)$} & \multirow{2}{*}{$t$} & \multirow{2}{*}{$F$} \\
\hline & Pre & Post & & Pre & Post & & \\
\hline height (cm) & $127.95 \pm 6.69$ & $130.18 \pm 6.94$ & $-10.217^{* * *}$ & $127.08 \pm 5.88$ & $128.43 \pm 5.33$ & $-3.590^{* *}$ & 3.432 \\
\hline weight $(\mathrm{kg})$ & $26.82 \pm 4.3$ & $26.65 \pm 4.23$ & 1.081 & $26.51 \pm 1.88$ & $27.76 \pm 2.55$ & $-3.960^{* *}$ & $13.120^{\# \#}$ \\
\hline BMI $\left(\mathrm{kg} / \mathrm{m}^{2}\right)$ & $16.3 \pm 1.75$ & $15.53 \pm 1.58$ & $10.086^{* * *}$ & $16.44 \pm 1.08$ & $16.84 \pm 1.13$ & -1.544 & $14.237^{\# \#}$ \\
\hline fat mass $(\mathrm{kg})$ & $6.12 \pm 2.04$ & $4.6 \pm 2.01$ & $7.208^{* *}$ & $5.89 \pm 0.89$ & $6.38 \pm 1.24$ & -1.831 & $31.198^{\# \# \#}$ \\
\hline$\%$ fat $(\%)$ & $22.4 \pm 5.51$ & $16.62 \pm 5.8$ & $7.532^{* *}$ & $22.26 \pm 3.09$ & $22.88 \pm 3.51$ & -0.763 & $31.285^{\# \# \#}$ \\
\hline LBM (kg) & $20.7 \pm 2.99$ & $22.05 \pm 3.31$ & $-5.343^{* *}$ & $20.63 \pm 1.83$ & $21.39 \pm 2.01$ & $-3.553^{* *}$ & 3.160 \\
\hline LBM (\%) & $77.58 \pm 5.46$ & $83.1 \pm 6.42$ & $-8.062^{* * *}$ & $77.76 \pm 3.17$ & $77.1 \pm 3.53$ & .810 & $30.750^{\# \# \#}$ \\
\hline
\end{tabular}

Values are means \pm SD.

EG: exercise group, CG: control group, BMI: body mass index, LBM: lean body mass

$*$ : significant different within group, ${ }^{* *}: p<0.01,{ }^{* * *}: p<0.001$

\#: significant group $\times$ time interaction effects, \#\#: $p<0.01$, \#\#\#: $p<0.001$ 
Table 3. Changes of factors relative to the brain nerve growth after 12-weeks aerobic exercise

\begin{tabular}{|c|c|c|c|c|c|c|c|}
\hline \multirow{2}{*}{ Item } & \multicolumn{2}{|c|}{ EG $(n=6)$} & \multirow{2}{*}{$t$} & \multicolumn{2}{|c|}{ CG $(n=8)$} & \multirow{2}{*}{$t$} & \multirow{2}{*}{$F$} \\
\hline & pre & post & & pre & post & & \\
\hline $\mathrm{GH}(\mathrm{ng} / \mathrm{ml})$ & $6.81 \pm 5.04$ & $10.93 \pm 4.8$ & $-2.701^{*}$ & $6.67 \pm 4.29$ & $6.09 \pm 3.89$ & 0.661 & $8.009^{\sharp}$ \\
\hline IGF-1 (ng/ml) & $193.68 \pm 106.28$ & $199.25 \pm 107.92$ & $-2.648^{*}$ & $178.65 \pm 52.87$ & $173.84 \pm 49.34$ & 1.723 & $7.782^{\#}$ \\
\hline estrogen $(\mathrm{pg} / \mathrm{ml})$ & $55.5 \pm 5.96$ & $61.23 \pm 7.57$ & -2.344 & $49.71 \pm 4.94$ & $52.63 \pm 6.38$ & -2.319 & 1.222 \\
\hline serotonin $(\mathrm{ng} / \mathrm{ml})$ & $61.08 \pm 33.94$ & $43.6 \pm 20.64$ & 2.553 & $56.19 \pm 19.77$ & $59.69 \pm 22.69$ & -.595 & $5.416^{\#}$ \\
\hline
\end{tabular}

Values are means \pm SD.

EG: exercise group, CG: control group, $\mathrm{GH}$ : growth hormone

*: significant different within group, *: $p<0.05, * *: p<0.01$

\#: significant group $\times$ time interaction effects, \#: $p<0.05$

후 평균값을 비교한 결과 $\mathrm{GH}(\mathrm{p}<0.05), \mathrm{IGF}-1 \quad(\mathrm{p}<0.05)$ 에서 유의한 차이를 보이며 증가한 것으로 나타났다.

\section{고 찰}

유산소운동이 신경성장인자 및 신경전달물질에 미치는 효 과를 알아보고자 유산소운동에 따른 GH, IGF-1, estrogen, serotonin의 변화를 비교·분석하였다.

$\mathrm{GH}$ 는 뇌하수체 전엽에서 분비되는 호르몬의 하나로 간이 나 지방 조직에서 당을 만들고 지방 분해에 관여하는 호르몬 이다. 또한 빼에서 연골의 형성, 근에서 아미노산의 섭취나 단백질 합성을 촉진하여 세포의 핵분열을 증가시키는 작용을 하는 물질이다[42]. 최근 $\mathrm{GH}$ 가 뇌에서 자가 분비되어 뇌기능 활성과 뇌세포 생성에 영향을 미치는 것으로 보고되었다 $[23,38,47]$.

본 연구에서 $\mathrm{GH}$ 는 운동 후 집단간 유의한 차이를 보이며 증가한 것으로 나타났으며, 각 집단내 운동 전·후 차이에서도 운동군은 유의한 차이를 보이며 증가하는 반면 대조군은 차이 가 없었다. 최근 운동이 성장호르몬에 미치는 영향에 관한 연 구들을 살펴보면 대부분의 연구 결과에서 운동이 $\mathrm{GH}$ 증가에 긍정적인 영향을 미친다고 보고하고 있어 $[5,30,57]$ 본 연구의 결과와 유사하다. 선행연구와 본 연구의 결과를 볼 때 유산소 운동이 $\mathrm{GH}$ 분비 증가를 통해 뼈 형성, 단백질 합성, 뇌기능 활성과 뇌세포 생성에 긍정적인 영향을 미친 것으로 생각한다.

또한 성장호르몬의 분비 정도는 운동 강도에 따라 차이가 있는데 저강도<고강도<중강도의 순서대로 변화량이 더 크다 고 보고되었으며[31,42], 초,중,고 여학생을 대상으로 8주간 저 강도, 중강도로 무용 활동을 시킨 결과 모든 집단에서 저강도 운동 보다 중강도운동 일 때 성장호르몬의 분비가 증가하였다 고 보고하였다[22]. 이러한 선행 연구의 결과는 저강도 운동은 운동의 효과가 중강도에 비해 낮아 성장에 큰 영향을 미치지 못하고, 고강도 시 운동으로 인한 피로감이 근육 및 내분비 호르몬에 영향을 주어 인체에 부정적인 영향을 주는 것으로 보인다. 따라서, 본 연구에서GH 의 유의한 증가는 중강도의 유산소운동이 $\mathrm{GH}$ 증가에 효과적으로 작용한 것으로 생각된

다.

신체조성의 변화는 $\mathrm{GH}$ 의 변화와 관련이 있으며, 실제로 운동에 의한 $\mathrm{GH}$ 의 증가는 지방의 운반 및 산화를 증가시켜 지방의 이용을 높이게 되기 때문에 체중, 체지방량 감소, 제지 방량 증가시킬 수 있다고 보고되었다[19]. 본 연구에서도 집단 간 유의한 차이를 보이며 $\mathrm{GH}$ 증가와 함께 운동군의 체중, $\mathrm{BMI}$, 체지방량 감소와 제지방률 증가 결과를 나타내었다. 선 행연구와 본 연구 결과를 볼 때 운동을 통한 $\mathrm{GH}$ 증가가 신체 조성의 긍정적 변화에 영향을 미친 것으로 생각된다.

IGF-1은 조직의 성장과 발달에 중요한 역할을 하며, 연골의 성장과 세포의 증식, 분화에도 작용한다. 또한 IGF-1은 뇌에서 생성되어 신경전달물질과 인식작용 $[10,12,28]$, 신경단위 성장 과 분화에 관여하며[2], 운동에 반응하여 뇌와 말초에서 발현 의 증가를 보인다[37,48]. 이렇게 증가된 IGF-1의 일부는 뇌혈 관장벽을 투과하여 뇌에서의 IGF-1 발현 증가에 영향을 미치 는 것으로 보고되었으며, IGF-1을 말초혈관을 통해 주입하면 운동을 수행한 것과 유사하게 해마의 $\mathrm{BDNF}$ 발현이 증가하는 것으로 보고되었다[10,44].

본 연구에서 IGF-1은 운동 후 집단간 유의차를 보이며 증가 한 것으로 나타났으며, 각 집단내 운동 전·후 차이에서도 운동 군은 유의한 차이를 보이며 증가하는 반면 대조군은 차이가 없었다. 선행연구에서도 본 연구 결과와 유사하게 지구성 운 동은 안정 시 총 IGF-1의 수준을 증가시킨다고 보고하였으며 [42,45], 운동 후 뇌와 말초신경의 IGF-1 수준이 증가되고, 뇌혈 관벽 주변을 가로지르는 신경 전달 물질이 증가된다고 보고되 었다[44]. 국내 여러 선행연구에서도 운동을 실시한 결과 IGF-1이 유의하게 증가하였다고 보고하였다[36,43]. 선행연구 와 본 연구의 결과를 볼 때 유산소운동이 IGH-1 분비 증가를 통해 아동의 뇌 신경단위 성장에 긍정적인 영향을 미친 것으 로 생각한다.

IGF-1의 증가 주요 요인이 체지방량의 감소, 활동량의 증가 로 인한 에너지 소비율의 증가, $\mathrm{BMI}$ 감소, $\mathrm{GH}$ 수용체 수의 증가, 간에서의 IGF-1의 합성을 위한 인슐린의 작용 증가, 근 섬유의 성장, 골격근 비대라는 보고[14]를 볼 때 본 연구에서 체중, BMI, 체지방량 감소와 제지방률 증가가 IGF-1 증가에 
영향을 미친 것으로 생각한다.

estrogen은 골 흡수 지표로써 인체 내 estrogen부족 시 골 조직망이 손상을 입는 것으로 보고되었다[13]. 뿐만 아니라 뇌 와 관련하여estrogen은 뇌신경세포 생성을 촉진시키며[32], 뇌 노화에도 영향을 미치는 것으로 보고되었으며[18,56], $\mathrm{BDNF}$ 생성에도 관여한다고 보고되었다[7,32,50]. 또한 운동에 의해 증가되는 estrogen, 뇌 혈류량, 포도당 이용효율 증가는 학습 수행능력의 향상과 밀접한 관련이 있는 것으로 나타났다 $[3,17,25,52,55]$. 운동에 의한 이러한 현상은 운동 시작 3 일만에 관찰이 될 만큼 빠르게 진행되는 것으로 나타났다[52].

본 연구에서 estrogen은 운동 후 집단 간 유의한 차이를 보 이지 않았으며, 각 집단 내 운동 전 - 후 차이에서도 운동군과 대조군 모두 유의한 차이가 없었다. estrogen의 운동 효과에 대한 선행연구에서 폐경여성을 대상으로 한 연구는 estrogen 이 증가하는 것으로 보고하고 있지만 본 연구와 같이 여자아 동에서는 유산소운동으로 estrogen이 변화되지 않는 것으로 보인다[35,54]. 신체활동에 의한 estrogen의 변화가 BDNF 수 준을 결정한다는 선행연구를 볼 때 신체활동에 의한 estrogen 의 변화는 뇌세포 생성 및 기능에 영향을 미치지 못하는 것으 로 생각된다[7].

serotonin은 중추신경계에 걸쳐 넓게 분포되어 있으며, 불 안, 충동 등과 같은 감정적 상태뿐만 아니라 운동 활동, 음식섭 취, 수면 및 성적 활동과 같은 생활양식에 관여하며, $\mathrm{BDNF}$ 발현 및 수준을 증가시키는 신경전달물질로 알려져 있다 $[4,24,27,46]$.

본 연구에서 serotonin은 운동 후 집단간 유의한 차이를 보 이며 감소한 것으로 나타났으며, 각 집단내 운동 전·후 차이에 서는 운동군과 대조군 모두 통계적으로 유의한 차이를 보이지 않았다. serotonin의 BDNF 발현 및 수준을 증가시키는 신경전 달물질로서의 기능을 볼 때 유산소운동 프로그램이 아동의 신경세포생성에 효과적이지 않은 것으로 보인다. 그러나 선행 연구에서 운동에 의해 신경전달물질인 serotonin이 증가되는 것으로 보고하고 있지만[41], 이렇게 증가된 serotonin의 활성 은 도파민성 뉴런의 억제를 통해 수행할 각성이나 동기를 감 소시킴으로써 피로를 유발하는 것으로 알려졌다[5]. 실제로 serotonin 농도의 감소에 의해 달리기 수행능력이 유의하게 향상되었다고 보고되었다[8,51]. 본 연구에서 운동 후 seroto$\operatorname{nin}$ 이 감소된 결과는 본 연구의 대상인 아동은 유산소운동 프 로그램 후 중추피로가 감소하는 것으로 해석되며, 오히려 스 트레스에 대한 적응력과 운동 수행능력이 증가되었다고 생각 한다.

\section{References}

1. ACSM. 2000. ACSM's guidelines for exercise testing and prescription. 6th ed., Philadelphia: Lippincott Williams \&
Wilkins.

2. Arsenijevic, Y. and S. Weiss. 1998. Insulin-like growth factor-I is a differentiation factor for postmitotic CNS stem cell-derived neuronal precursors: distinct actions from those of brain-derived neurotrophic factor. J. Neurosci. 18, 21182128.

3. Avery, R. A., J. S. Franowicz, C. Studholme, C. H. van Dyck, and A. F. Arnsten. 2000. The alpha-2A-adrenoceptor agonist, guanfacine, increases regional cerebral blood flow in dorsolateral prefrontal cortex of monkeys performing a spatial working memory task. Neuropsychopharmacology 23, 240-249.

4. Azmitia, E. C. and P. M. Whitaker-Azmitia. 1991. Awakening the sleeping giant: anatomy and plasticity of the brain serotonergic system. J. Clin. Psychiatry. 52, 4-16.

5. Back, E. J. and M. G. Lee. 2007. Effects of an 8-week combined training of walking and rope skipping on body composition, physical fitness, blood Lipid profiles, and growth hormone in elementary students. The Korean Journal of Physical Education 46, 461-472.

6. Bailey, S. P., J. M. Davis, and E. N. Ahlborn. 1993. Serotonergic agonists and antagonists affect endurance performance in the rat. Int. J. Sports Med. 14, 330-333.

7. Berchtold, N. C., J. P. Kesslak, C. J. Pike, P. A. Adlard, and C. W. Cotman. 2001. Estrogen and exercise interact to regulate brain-derived neurotrophic factor mRNA and protein expression in the hippocampus. Eu.r J. Neurosci. 14, 1992-2002.

8. Blomstrand, E. and B. Saltin. 2001. BCAA intake affects protein metabolism in muscle after but not during exercise in humans. Am. J. Physiol. Endocrinol. Metab. 281, 365-374.

9. Blumenthal, J. A., C. F. Emery, D. J. Madden, S. Schniebolk, M. Walsh-Riddle, L. K. George, D. C. McKee, M. B. Higginbotham, F. R. Cobb, and R. E. Coleman. 1991. Long-term effects of exercise on psychological functioning in older men and women. J. Gerontol. 46, 352-361.

10. Carro, E., A. Nuñez, S. Busiguina, and I. Torres-Aleman. 2000. Circulating insulin-like growth factor I mediates effects of exercise on the brain. J. Neurosci. 20, 2926-2933.

11. Carro, E., A. Nunez, S. Busiguina, and I. Torres-Aleman. 2001. Circulating insulin-like growth factor I mediates the protective effects of physical exercise against brain insults of different etiology and anatomy. J. Neurosci. 21, 5678-5684.

12. Carter, C. S., M. M. Ramsey, and W. E. Sonntagm. 2002. A critical analysis of the role of growth hormone and IGF-1 in aging and lifespan. Trends Genet 18, 295-301.

13. Dalsky, G. P. 1990. Effect of exercise on bone: permissive influence of estrogen and calcium. Med. Sci. Sports Exerc. 22, 281-285.

14. Dills, D. G., C. Allen, M. Palta, D. J. Zaccaro, R. Klein, and D. D'Alessio. 1995. Insulin-like growth factor-I is related to glycemic control in children and adolescents with newly diagnosed insulin-dependent diabetes. J. Clin. Endocrinol. Metab. 80, 2139-2143.

15. Dishman, R. K. 1997. Exercise, Brain and behavior. Med. Sci. Sports Exerc. 29, 37-38. 
16. Eriksson, P. S., E. Perfilieva, T. Björk-Eriksson, A. M. Alborn, C. Nordborg, D. A. Peterson, and F. H. Gage. 1998. Neurogenesis in the adult human hippocampus. Nat. Med. 4, 1313-1317.

17. Fordyce, D. E. and J. M. Wehner. 1993. Physical activity enhances spatial learning performance with an associated alteration in hippocampal protein kinase C activity in C57BL/6 and DBA/2 mice. Brain Res. 619, 111-119.

18. Garcia-Segura, L. M., I. Azcoitia, and L. L. DonCarlos. 2001. Neuroprotection by estradiol. Prog. Neurobiol. 63, 29-60.

19. Gertner, J. M. 1993. Effects of growth hormone on body fat in adults. Horm. Res. 40, 10-15.

20. Gould, E., A. J. Reeves, M. Fallah, P. Tanapat, C. G. Gross, and E. Fuchs. 1999. Hippocampal neurogenesis in adult Old World primates. Proc. Natl. Acad. Sci. USA. 96, 5263-5267.

21. Gould, E., A. J. Reeves, M. S. Graziano, and C. G. Gross. 1999. Neurogenesis in the neocortex of adult primates. Sci. 286, 548-552.

22. Han, S. C. 2005. The Change of Plasma Cortisol, White Blood Corpuscle to Exercise Intensity. K. Sport Res. 16, 421-428.

23. Harvey, S., I. Lavelin, and M. Pines. 2002. Growth hormone $(\mathrm{GH})$ action in the brain: neural expression of a GH-response gene. J. Mol. Neurosci. 18, 89-95.

24. Heils, A., A. Teufel, S. Petri, G. Stöber, P. Riederer, D. Bengel, and K. P. Lesch. 1996. Allelic variation of human serotonin transporter gene expression. J. Neurochem. 66, 2621-2624.

25. Hengemihle, J. M., O. Abugo, J. Rifkind, E. Spangler, D. Danon, and D. K. Ingram. 1996. Chronic treatment with human recombinant erythropoietin increases hematocrit and improves water maze performance in mice. Physiol. Behav. 59, 153-156.

26. Hill, R. D., M. Storandt, and M. Malley. 1993. The impact of long-term exercise training on psychological function in older adults. J. Gerontol. 48, 12-17.

27. Holmes, A., D. L. Murphy, and J. N. Crawley. 2002. Reduced aggression in mice lacking the serotonin transporter. Psychopharmacology 161, 160-167.

28. Holzenberger, $M$, J. Dupont, B. Ducos, P. Leneuve, A. Géloën, P. C. Even, P. Cervera, and Y. Le Bouc. 2003. IGF-1 receptor regulates lifespan and resistance to oxidative stress in mice. Nature 421, 182-187.

29. Hur, S. and J. H. Jang. 2009. The Effects of After-School New Sports Exercise Program on Body Composition and Blood Components in Obese Elementary Boys. . Journal of physical growth and motor development 17, 73-80.

30. Jang, J. H., and S. Hur. 2008. Comparison of obesity indices, plasma growth hormone and insulin-Like growth factor-1 according to exercise type in obese high school girls. The Korean Journal of Physical Education 47, 371-381.

31. Kim, H. S. 2004. Effects of Dance on the Growth Hormone and Insulin-Like Growth Factor 1 in Pubertal Girls. Journal of Physical Growth and Motor Development 12, 169-177.

32. Klintsova, A. Y. and W. T. Greenough. 1999. Synaptic plasticity in cortical systems. Curr. Opin. Neurobiol. 9, 203-208.

33. Kubitz, K. A. and A. A. Mott. 1996. EEG power spectral densities during and after cycle ergometer exercise. Res. Q.
Exerc. Sport 67, 91-96.

34. Kubitz, K. A. and K. Pothakos. 1997. Does aerobic exercise decrease brain activation? J. Sport and Exercise Psychol. 19, 291-301.

35. Lanfranco, F., L. Gianotti, R. Giordano, M. Pellegrino, M. Maccario, and E. Arvat. 2003. Ageing, growth hormone and physical performance. J. Endocrinol. Invest. 26, 861-872.

36. Lee, K. H., T. U. Kim, T. G. Park, H. J. Kim, C. H. Park, and M. K. Choi. 2008. Effects of Jumping Rope and Swiss Boll Exercise to Child GH, IGF-1, CT. Journal of Sport and Leisure Studies 33, 1065-1074.

37. Markowska, A. L., M. Mooney, and W. E. Sonntag. 1998. Insulin-like growth factor-1 ameliorates age-related behavioral deficits. Neuroscience 87, 559-569.

38. McLenachan, S., M. G. Lum, M. J. Waters, and A. M. Turnley. 2009. Growth hormone promotes proliferation of adult neurosphere cultures. Growth Horm. IGF Res. 19, 212-218.

39. Meeusen, R., J. Roeykens, L. Magnus, H. Keizer, and K. De Meirleir. 1997. Endurance performance in humans: the effect of a dopamine precursor or a specific serotonin (5-HT2A/2C) antagonist. Int. J. Sports Med. 18, 571-577.

40. Neeper, S. A., F. Gómez-Pinilla, J. Choi, and C. W. Cotman. 1996. Physical activity increases mRNA for brain-derived neurotrophic factor and nerve growth factor in rat brain. Brain Res. 726, 49-56.

41. Nibuya, M., S. Morinobu, and R. S. Duman. 1995. Regulation of BDNF and trkB mRNA in rat brain by chronic electroconvulsive seizure and antidepressant drug treatments. J. Neurosci. 15, 7539-7547.

42. Nicklas, B. J., A. J. Ryan, M. M. Treuth, S. M. Harman, M. R. Blackman, B. F. Hurley, and M. A. Rogers. 1995. Testosterone, growth hormone and IGF-I responses to acute and chronic resistive exercise in men aged 55-70 years. Int. J. Sports Med. 16, 445-450.

43. Park, I. R. 2004. The Effects of Complex exercise program on Body composition, Growth hormone and IGF-1 of obese girls in middle school. The Korean Journal of Physical Education 43, 419-427.

44. Reinhardt, R. R. and C. A. Bondy. 1994. Insulin-like growth factors cross the blood-brain barrier. Endocrinol. 135, 1753-1761.

45. Roelen, C. A., W. R. de Vries, H. P. Koppeschaar, C. Vervoorn, J. H. Thijssen, and M. A. Blankenstein. 1997. Plasma insulin-like growth factor-I and high affinity growth hormone-binding protein levels increase after two weeks of strenuous physical training. Int. J. Sports Med. 18, 238-241.

46. Russo-Neustadt, A., T. Ha, R. Ramirez, and J. P. Kesslak. 2001. Physical activity-antidepressant treatment combination: impact on brain-derived neurotrophic factor and behavior in an animal model. Behav Brain Res. 120, 87-95.

47. Scheepens, A., T. A. Möderscheim, and P. D. Gluckman. 2005. The role of growth hormone in neural development. Horm. Res. 3, 66-72.

48. Schwarz, A. J., J. A. Brasel, R. L. Hintz, S. Mohan, and D. M. Cooper. 1996. Acute effect of brief low- and high-in- 
tensity exercise on circulating insulin-like growth factor (IGF) I, II, and IGF-binding protein-3 and its proteolysis in young healthy men. J. Clin. Endocrinol. Metab. 81, 3492-3497.

49. Shim, J. H., and T. S. Park. 2002. Pilot study of relation between physical activity experience in infancy and developmental tendency of fundamental motor element in childhood. Journal of physical growth and motor development 10, 91-102.

50. Singh M., E. M. Meyer, and J. W. Simpkins. 1995. The effect of ovariectomy and estradiol replacement on brain-derived neurotrophic factor messenger ribonucleic acid expression in cortical and hippocampal brain regions of female Sprague-Dawley rats. Endocrinol. 136, 2320-2324.

51. Strüder, H. K. and H. Weicker. 2001. Physiology and pathophysiology of the serotonergic system and its implications on mental and physical performance. Part I. Int. J. Sports Med. 22, 467-481.

52. Swain, R. A., A. B. Harris, E. C. Wiener, M. V. Dutka, H. D. Morris, B. E. Theien, S. Konda, K. Engberg, P. C. Lauterbur, and W. T. Greenough. 2003. Prolonged exercise induces angiogenesis and increases cerebral blood volume in primary motor cortex of the rat. J. Neurosci. 117, 10371046.

53. Trejo, J. L., E. Carro, and I. Torres-Aleman. 2001. Circulating insulin-like growth factor I mediates exercise-induced increases in the number of new neurons in the adult hippocampus. J. Neurosci. 21, 1628-1634.

54. Underwood, L. E. and P. Backeljauw. 1993. Therapy with recombinant human insulin-like growth factor I in children with insensitivity to growth hormone and in catabolic conditions. J. Intern. Med. 234, 571-577.

55. Vissing, J., M. Andersen, and N. H. Diemer. 1996. Exercise-induced changes in local cerebral glucose utilization in the rat. J. Cereb. Blood Flow. Metab. 16, 729-736.

56. Wise P. M., D. B. Dubal, M. E. Wilson, S. W. Rau, and Y. Liu. 2001. Estrogens: trophic and protective factors in the adult brain. Front. Neuroendoc. 22, 33-66.

57. Yeo, N. H., K. S. Oh, Y. R. Cha, and S. H. Kang. 2008. Effect of Yoga Exercise Program on Catecholamine and Growth Hormone in Pre and Postmenopausal Middle Aged Women. Korean Journal of Sport Science 19, 31-40.

\title{
초록 : 유산소운동이 여자 아동의 뇌세포 생성 관련인자에 미치는 영향
}

\author{
편미영 · 조한샘 $\cdot$ 전재영 · 김종원 · 이경희 · 임춘규 · 김태운 ${ }^{*} \cdot$ 김현준 $^{2} \cdot$ 곽이섭 $^{3} \cdot$ 고기준 $^{4}$ \\ ( ${ }^{1}$ 부산대학교 체육교육과, ${ }^{2}$ 경남대학교 체육교육과, ${ }^{3}$ 동의대학교 체육교육과, ${ }^{4}$ 대구미래대학 스포츠학과)
}

운동은 신경의 생성, 적응, 보호 기능을 통해 뇌 기능 및 생성에 긍정적인 영향을 미치며, 유산소운동은 뇌신경 성장인자(GH, IGF-1, estrogen, serotonin)를 변화시키는 것으로 보고되었다. 본 연구는 여자 아동의 뇌기능 발달 및 뇌세포 생성 유도인자의 유산소운동 효과를 알아보고자 유산소운동 프로그램에 따른 뇌신경 성장인자 $(\mathrm{GH}$, IGF-1, estrogen, serotonin)의 변화를 분석하여 다음과 같은 결론을 얻었다. 반복측정 분산분석에 의해 운동군과 대조군의 평균을 비교한 결과 유산소운동은 집단간 유의한 차이를 보이며 체중, $\mathrm{BMI}$, 체지방량, 체지방률을 감소 시켰으며, 제지방률을 증가시켰다. 또한 뇌신경 성장인자인 serotonin을 감소시켰으며, GH와 IGF-1을 증가시켰 다. 본 연구결과 유산소운동 프로그램이 아동의 체중, $\mathrm{BMI}$, 체지방, 체지방률 감소와 제지방률 증가에 효과적이 다. 또한 serotonin이 운동 후 감소된 결과를 볼 때 유산소운동 프로그램이 아동의 중추피로 감소에 효과적이며, GH, IGF-1의 운동 후 증가된 결과를 볼 때 유산소운동이 아동의 뇌기능 발달 및 뇌세포 생성 유도에 긍정적인 프로그램임을 알 수 있다. 